\title{
The Improvement Model of Existence Effect towards Human Resources
}

\author{
Arizqi \\ Dept. of Management, Economics Faculty, Islam Sultan Agung University (UNISSULA), \\ Jl. Raya Kaligawe Km. 4 PO Box. 1054, Semarang 50112, Indonesia.
}

\begin{abstract}
Abstrak. Efek eksistensi merupakan eksistensi sumber daya manusia yang muncul dari efek atau sesuatu yang telah dilakukan oleh sebuah aktivitas. Efek eksistensi dalam penelitian ini merupakan eksistensi mahasiswa yang dimunculkan dari kegiatan belajar mengajar dikelas. Begitu pentingnya sebuah efek eksistensi sebagai output kegiatan belajar mengajar, maka penelitian ini bertujuan untuk menguji pengaruh responsibility, attractiveness, emphaty, dan juga competency dari seorang pengajar dalam mempengaruhi peningkatan efek eksistensi mahasiswa di Universitas Islam Sultan Agung (UNISSULA) Semarang. Jenis penelitian ini merupakan penelitian penjelasan (Explanatory Research) yang berusaha mengetahui hubungan antar variabel penelitian. Penelitian dilakukan dengan metode survey dengan menyebarkan kuesioner kepada 212 mahasiswa dari dari 4 mata kuliah 5 kelas. Analisis data penelitian dilakukan dengan pengujian structural equational modelling (SEM) dan menggunakan pendekatan varians (partial least square), kemudian pengolahan data didukung dengan aplikasi SmartPLS. Hasil penelitian menunjukkan bahwa efek eksistensi sumber daya manusia didalam organisasi dapat ditingkatkan melalui peningkatan emphaty dosen terhadap mahasiswa. Kemudian untuk meningkatkan kompetensi seorang dosen dapat ditingkatkan melalui peningkatan attractiveness atau metode pembelajaran yang atraktiv ketika melakukan pembelajaran dikelas. Sementara itu responsibility tidak mampu menjelaskan terhadap efek eksistensi mahasiswa.
\end{abstract}

Kata Kunci : Tanggung jawab, atraktif, empati, kompetensi dan efek eksistensi.

\begin{abstract}
Existancy Effect is the existence of human resources that arise from the effect or something that has been done by an activity. Existancy Effect in this research is the existence of students arising from teaching and learning activities in class. Once the importance of an Existancy Effect as an output of teaching and learning activities, then this research aims to examine the influence of responsibility, attractiveness, empathy, and also competency in influencing the improvement of existency effect toward human resources (students) at Sultan Agung Islamic University (UNISSULA) Semarang. The type of this research is an explanatory research that seeks to determine the relationship between research variables. This research was conducted through survey method by distributing questionnaires to 212 students from 4 courses in 5 classes. The research data analysis used Structural Equation Modeling (SEM) and used partial least square. The data processing was supported by SmartPLS application. The results showed that the existence effect of human resources in organizations can be improved through increasing the empathy of lecturers with students, Furthermore, in order to improve the lecturer's competency, it needs an attractiveness in the learning method. Meanwhile responsibility cannot explain the existance effect of students.
\end{abstract}

Keywords: responsibility, attractiveness, emphaty, competency, existence effect. 


\section{INTRODUCTION}

The teaching and learning process in class is always related to three things; first, lecturer as the organizer of learning, second, students as the subject and object of learning, third is learning instruments. Thus, the teaching and learning process in University is carried out by lecturer and students. Lecturers as a learning locomotive must know the changes, developments, talents and interests of their students. In teaching, lecturers have duty as learners who have the responsibility and professionalism during the learning activities. Lecturers not only give information but also provide learning facilities so that the learning process is more adequate (Sagala, 2008). Lecturers are also required to play creative learning and progress. It is shown through the students' ability in implementing the lecture material taught by lecturers. Students are inspired to increase the learning motivation, to think logically, and behave better.

There is a belief that the change in students towards a better direction is determined by the role played by the lecturer. Students must also be well understood by paying attention to their basic interests and abilities. Students have different complexities from one another. There are students who are quick to understand and some of them are slow. The slow learners usually need a repetitive learning process so that they can understand. These facts must receive attention from the lecturer in order to create a positive change. Fast and slow changes in students may influenced by many things, one of the influence is the strategy applied by lecturers in learning that is personally acceptable to all students.

The ability development of students in university starts from the learning method implemented by the lecturer. The concept of education is not only about examinations ro measure the knowledge transfer, but more broadly, it includes the formation of skills and basic attitudes, such as criticism, creativity also openness to innovation and various inventions (Mutmainah, 2008). Mutmainah (2008) explained that lecturers are not only assigned to transfer knowledge, but more than, lecturers should act as an enlightenment agent. Thus, lecturers must have competence so they can explain the material clearly and also can give the real applications to students. Competence is an ability that must be possessed by educators in order to achieve learning goal. The learning goal is student can apply the material in the real life. This statement is in line with research conducted by Mudayati (2008) that good mastery of material by lecturers can improve the student achievement index.

Besides competency, lecturers also must have responsibilities, empathy for students, and an interesting learning methods in order to make the students get an existence effect from the learning process. Existence effect is a condition where students feel motivated in learning, able to implement the lecture material, able to think logically and behave well. The responsibility of the lecturer is not only related with the presence of teaching, but also the suitability between the material delivered with the lecture contract, until students are able to master and apply the material in real life. In order to achieve the above goals, an attractive learning method is highly recommended. The lecturers are expected to be able to present an interesting, interactive, clear and understandable material.

Although the attractive learning method has long been introduced, there are lecturers still use traditional learning methods (oratory method). In traditional learning method, the lecturer is considered as the only source of knowledge and takes the central role in the learning process. This traditional method can result a low learning effectiveness, so that the students' understanding towards the material is also low. It triggers only few of students who can implement the lecture material in the reality. 
Therefore, traditional learning methods have not been able to sharpen the students' analytical skills, sensitivity to problems, practice problem solving and the ability to evaluate problems holistically (Mutmainah, 2008).

Regarding to the problems above, this research needs to be conducted for several reasons. First, this research will measure the competence, the attractive learning methods, responsibilities, and empathy for students possessed by lecturers. So that the learning process in the class is not monotonous and passive. Second, this research will prove that in the learning process needs to use real cases to help students implement in the real life. Third, this research will explain that the delivery of material in the learning process must be clear, and can be understood by students.

\section{Existence Effect}

Existence effect is an existence effect of students from something that has been done before, in this case is related with an attractive learning method, competence, responsibility, and empathy of lecturers in teaching and learning process in the classroom. The ndicators of existance effect include; students can implement lecture material taught by lecturers, students are inspired to increase learning motivation, students are inspired to think logically, and behave better.

\section{Responsibility}

Lecturer is someone who works as an educator based on education and expertise. Lecturer is appointed by the university with the main task to educate (Arwildayanto, 2012). One of the duties and responsibilities of a lecturer is to conduct education and teaching, besides other duties and responsibilities, such as research and community service. According to Surya (2005) stated that professional teachers will be reflected in the implementation of their dedication towards tasks. It is also marked by their expertise in both material and method. Moreover, the teachers' professionalism is also demonstrated through their responsibilities in conducting all his services.

Professional teachers should be able to bear the responsibilities as teachers to their students. Sofyanti (2007) in her research stated that there is no significant effect of teacher professionalism towards student achievement. The University of Birmingham (2010) on "Lecturer in Urban Planning and Resilience", suggested that one of the responsibilities of a lecturer is teaching at all levels and study programs of the University. Lecturers also plan and review their own teaching approaches so that the lecturers know the good and bad during its learning process so that the students are able to implement the material in real life.

H1: Responsibility has significant influence towards existence effect

\section{Atractiveness}

Lecturer is central figures during the learning activity in the classroom. Lecturer as educator in the classroom requires improvement and creativity. One of the improvement is such as an attractiveness during the class. Attractiveness is one of the teaching methods that can be used by a teacher in a class so that the interactions during teaching and learning process in class are created with full of attachment and enthusiasm. According to Nabawi (2010), stated that lecturers who use attractive ways in teaching will create a pleasant learning atmosphere and help students to more easily understand the lessons. Attractive learning methods can also motivate students to learn and have an impact on the learning achievement. Lecturers who are attractive in teaching will always deliver the lecture material in creative way. A teacher's creativity in teaching will have an impact on student interest during the learning process in the classroom. Whatever the lecturer does in the learning process will determine how much the student's interest in learning. It is 
because, students who are not interested to a subject depends on the way the lecturer delivers the material in front of the class (Nordin, 2010). This can be seen in through the students' behavior in the learning process. There are students who are serious in paying attention and some are ignoring and even being indifferent to the lecturer ass. The attitude of the lecturer in explaining the lesson has a significant influence toward students' motivation in class (Nordin, 2010).

The more attractive the method used by a lecturer during the learning process, will require lecturers to present the lectures in an interesting way, interacting with the students, deliver lectures in a clear and understandable way, and use a variety of styles and methods in delivering the material. These indicators will require lecturers to develop their potentcy, develop their skills, communication skills, and the media used in the development. So that the competence of a lecturer will increase.

H2: Attractiveness has significant influence toward Competency

\section{Emphaty}

According to Stotland; Mehrabian \& Epstein; Hoffman (2001), empathy is an emotional response of others' emotional experiences. Bayer (2004) stated that empathy is more than just an awareness towards others' emotions, but also feel the emotions contained in it, and expressing the feelings in an emotional way. In the Oxford dictionary, empathy is defined as "the ability to understand and share the feelings of another". This means that empathy is the ability to understand and share feelings to others. Thus, the empathy of a lecturer towards students is one of the example. Lecturers' empathy towards students in the teaching and learning process in class is very important because it determines student learning achievement. The empathy of lecturers can be implemented by the enthusiasm and love in teaching. In addition, the empathy can be shown through the lecturers respect the students, lecturers are able to make a fun learning situations, and care about the understanding of students toward the lecture material.

Motivating students is also a form of lecturer empathy for their students. Motivate to learn, to do positive things, and to improve achievement. Uno (2010) argued that the essemce of learning motivation is internal and external encouragement to students who are learning to make changes in behavior. Learning motivation is a very determining factor in one's learning success. A student who has a high level of motivation will always find out and try something new. In other words, more or less motivation of a student will affect his learning achievement. According to Callahan and Clack (1988), student motivation has a very decisive role in student success to achieve the optimal learning. So that lecturers need to raise the student motivation by creating a conducive atmosphere. This atmosphere can be built through two-way communication, using appropriate learning methods which is supported by mastery of the material. Thus the learning process becomes interesting, students become enthusiastic and it improves the student learning achievement.

H3: Emphaty has significant influence toward existance effect

\section{Competency}

Various definitions of competency have been put forward. According to law article 1 about Teachers and Lecturers, competency is a set of knowledge, skills and behaviors that must be possessed, internalized by teachers and lecturers in carrying out professional duties (Dikti, 2010). According to Littrell (2008), competency is the mental and physical strength to perform and the skills learned through practice. Similarly, Spencer (2008) defined competency as an underlying characteristic of individuals related with excellent performance in work. Besides having knowledge, skills, attitudes, as professional educators and scientists in Islamic Universities (PTAI) environment, lecturers must have competency in carrying out their duties. The competencies are first, 
professional competency as academic insight and the depth of lecturers' knowledge about the scientific material. Second, pedagogical competence, the mastery of lecturers on various approaches, methods, classroom management, and evaluation of learning in accordance with the characteristics of the material and student development. Third, personality competency, an ability of lecturers to properly present themselves as role models, show enthusiasm and love for their profession. Fourth, social competency, the lecturers' ability to value diversity, active in various social activities, and able to work in team. Schaltz (1970) stated that knowledge influences individual work spirit. Thus that the initial knowledge has a strong contribution toward the achievement, knowledge and learning objective of students.

H4: Competency has significant influence toward existence effect

\section{Research Empirical Model}

Based on the literature review and hypothesis development as explained above, the emipirical model of this research is described below:

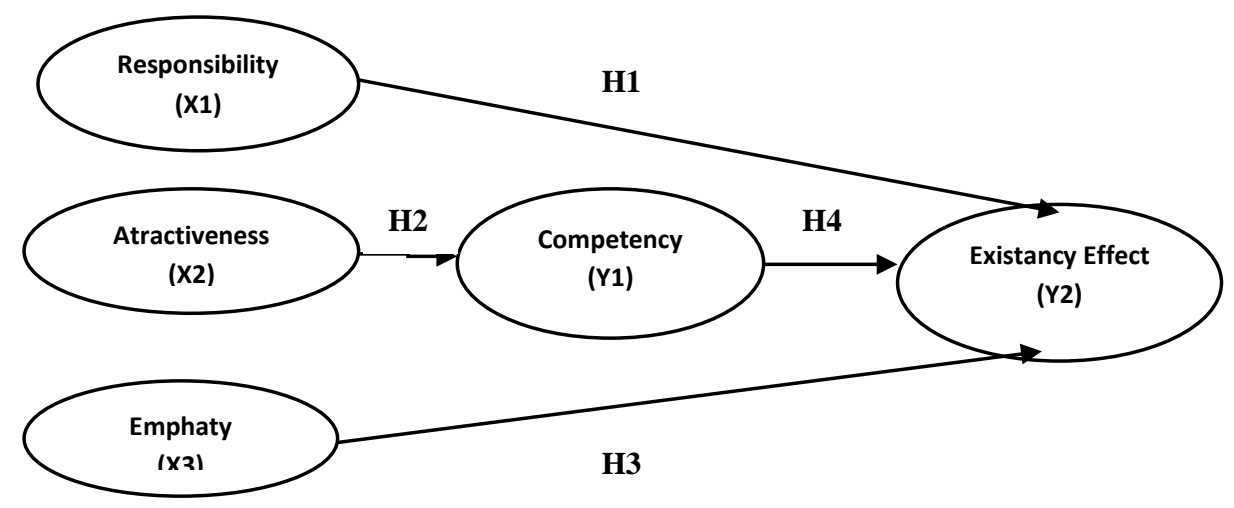

Figure 1. Research Empirical Model

From figure 1, responsibility and empathy influence the existence effect. Meanwhile the attractive learning methods influence competency, which also influence the existence effect. The responsibility, attractiveness, and empathy are independent variable. Whereas the dependent variables are competency and existence effect. Competency also acts as an intervening variable between the relationship of attractiveness with existence effect.

\section{METHOD}

This type of research is an explanatory research that tries to find out the relationship between the research variables. The essence of this study is the causal relationship between variables through hypothesis testing. The research data came from respondents and literature/Books/Journals. The type of research data is primary and secondary data. Data collection in this study was using questionnaire. The research was conducted through survey method by distributing questionnaires to 212 students from 4 courses in 5 classes. The research data analysis was conducted by testing the Structural Equation Modeling (SEM) and using the variance approach (partial least square). Meanwhile the data processing was supported by SmartPLS application. The variable operational definition of this research is described in the following table 1: 
Table 1. Variable Operational Definition

\begin{tabular}{|c|c|c|c|}
\hline NO & VARIABLE & DOV & INDICATOR \\
\hline 1. & Responsibility & $\begin{array}{l}\text { Lecturers' responsibility } \\
\text { towards the implementation } \\
\text { of education and teaching in } \\
\text { class with their students. }\end{array}$ & $\begin{array}{l}\text { 1. The lecturers plan the lecture } \\
\text { activities well } \\
\text { 2. The lecturers are responsible for } \\
\text { the completion of lecture material }\end{array}$ \\
\hline 2. & Atractiveness & $\begin{array}{l}\text { Attractiveness is one of } \\
\text { teaching methods that can be } \\
\text { used by a lecture in class. } \\
\text { This method is full of } \\
\text { attractiveness for students so } \\
\text { that the interaction during } \\
\text { learning process is created } \\
\text { with bonding and enthusiasm. }\end{array}$ & $\begin{array}{l}\text { 1. The lecturers present the material } \\
\text { with an interesting way } \\
\text { 2. The lecturers give lecture by } \\
\text { interacting with the students } \\
\text { 3. The lecturers deliver the lecture } \\
\text { clearly and understandable } \\
\text { 4. The lecturers use various style and } \\
\text { methods in delivering the lecture }\end{array}$ \\
\hline 3. & Emphaty & $\begin{array}{l}\text { The ability to understand and } \\
\text { share a feeling between } \\
\text { lecturer and student during } \\
\text { the learning process. }\end{array}$ & $\begin{array}{l}\text { 1. The lecturers have passion in } \\
\text { teaching } \\
\text { 2. The lecturers respect their students } \\
\text { 3. The lecturers are able to make a } \\
\text { fun learning situation } \\
\text { 4. The lecturers care toward their } \\
\text { material in class }\end{array}$ \\
\hline 4. & Competency & $\begin{array}{l}\text { The individual ability of } \\
\text { lecturer related with his } \\
\text { profession as educator }\end{array}$ & $\begin{array}{l}\text { 1. The lecturers link the material with } \\
\text { the real example } \\
\text { 2. The lecturers correlate the material } \\
\text { with Islamic value } \\
\text { 3. The lecturers master the } \\
\text { material/have a comprehensive } \\
\text { knowledge in their field of study. }\end{array}$ \\
\hline 5. & $\begin{array}{l}\text { Existence } \\
\text { Effect }\end{array}$ & $\begin{array}{l}\text { Student existence or the result } \\
\text { of attractive, competent, } \\
\text { responsible and emphatic } \\
\text { learning method of lecturers } \\
\text { in the class. }\end{array}$ & $\begin{array}{l}\text { 1. Student can implement the material } \\
\text { taught by lecturer in the class. } \\
\text { 2. Students are inspired to increase } \\
\text { the learning motivation. } \\
\text { 3. Students are inspired to think } \\
\text { logically and behave better. } \\
\text { 4. Students consider lecturer as the } \\
\text { favorite one during the learning } \\
\text { process. }\end{array}$ \\
\hline
\end{tabular}

responsibility, attractiveness, emphaty,

\section{RESULT AND DISCUSSION}

The Result of Outer Model

Based on the convergent validity test, it can be known that the indicators of competency and existence effect have outer loading value for $>0,6$ so that the variable indicator of work motivation is Valid.

Table 2. Convergent validity research variable 


\begin{tabular}{lcccc}
\hline & $\begin{array}{c}\text { Original Sample } \\
\text { Estimate }\end{array}$ & $\begin{array}{c}\text { Mean of } \\
\text { Subsamples }\end{array}$ & $\begin{array}{c}\text { Standard } \\
\text { Deviation }\end{array}$ & T-Statistic \\
\hline Xesponsibility & 0.962 & 0.959 & 0.022 & 43.613 \\
X1.2 & 0.967 & 0.968 & 0.013 & 76.128 \\
Atractiveness & 0.915 & & & \\
X2.1 & 0.912 & 0.914 & 0.030 & 30.495 \\
X2.2 & 0.932 & 0.904 & 0.051 & 17.964 \\
X2.3 & 0.891 & 0.931 & 0.029 & 32.471 \\
X2.4 & & & 0.036 & 24.558 \\
Emphaty & 0.872 & 0.871 & & \\
X3.1 & 0.898 & 0.891 & 0.062 & 13.989 \\
X3.2 & 0.911 & 0.910 & 0.051 & 17.525 \\
X3.3 & 0.897 & 0.894 & 0.030 & 30.376 \\
X3.4 & & & 0.053 & 16.965 \\
Competency & 0.899 & 0.900 & 0.035 & \\
Y1.1 & 0.892 & 0.889 & 0.036 & 25.557 \\
Y1.2 & 0.874 & 0.864 & 0.071 & 12.401 \\
Y1.3 & & & \\
Existancy Effect & 0.906 & 0.903 & 0.046 & 19.890 \\
Y2.1 & 0.953 & 0.952 & 0.017 & 57.482 \\
Y2.2 & 0.924 & 0.918 & 0.054 & 17.121 \\
Y2.3 & 0.881 & 0.881 & 0.049 & 17.965 \\
Y2.4 & & & \\
\hline
\end{tabular}

From the output result of SmartPLS above, all constructs have composite reliability value above 0.7 . It can be concluded that all

Tabel 3. Composite Reliability

\begin{tabular}{ll}
\hline & Composite Reliability \\
\hline Responsibility & 0.964 \\
Atractiveness & 0.952 \\
Emphaty & 0.941 \\
Competency & 0.918 \\
Existancy Effect & 0.954 \\
\hline
\end{tabular}

research variables are reliable. Following is the table of composite reliability value:

\section{Inner Model Result}

Assessing the inner model is about seeing the relationship between latent constructs. It can be known by figuring out the estimated results of the path parameter coefficients and their level of significance (Ghozali, 2008). The basis used in hypotheses testing is the value contained in the output result for inner weight as shown in table 4 below:

Table 4. Result for inner weight 


\begin{tabular}{lcccc}
\hline & $\begin{array}{c}\text { original sample } \\
\text { estimate }\end{array}$ & $\begin{array}{c}\text { mean of } \\
\text { subsamples }\end{array}$ & $\begin{array}{c}\text { Standard } \\
\text { deviation }\end{array}$ & T-Statistic \\
\hline Responsibility -> Existancy Effect & -0.026 & -0.044 & 0.149 & 0.174 \\
Atractiveness -> Competency & 0.871 & 0.872 & 0.042 & 20.571 \\
Emphaty -> Existancy Effect & 0.690 & 0.713 & 0.182 & 3.789 \\
Competency -> Existancy Effect & 0.255 & 0.249 & 0.227 & 1.123 \\
\hline
\end{tabular}

Responsibility is not significant toward existence effect. It is proven by the parameter coefficient value is -0.026 and the significant t-statistic is $0.174<\mathrm{t}$-table 1.971 . Therefore hypothesis 1 which stated that Responsibility has significant influence toward existence effect is rejected. Attractiveness has significant influence toward competency. It is proven by the parameter coefficient value is 0.871 and significant t-statistic $20.571>$ t-tabel 1.971 . So that hypothesis 2 which stated attractiveness has significant influence toward competency is accepted. Emphaty has significant influence toward existence effect. It is proven by the parameter coefficient value is 0.690 and significanr tstatistic $3.789>\mathrm{t}$-tabel 1.971. So that hypothesis 3 which stated that emphaty has significant influence toward existance effect is accepted. Competency is not significant toward existence effect. It is known by the parameter coefficient value is 0.255 and significant t-statistic $1.123<\mathrm{t}$-tabel 1.971 . Thus the hypothesis 4 which stated that competency has significant influence toward existence effect is rejected.

Tabel 5. R-Square

\begin{tabular}{lc}
\hline & R-square \\
\hline Responsibility & 0.000 \\
Atractiveness & 0.000 \\
Emphaty & 0.000 \\
Competency & 0.758 \\
Existancy Effect & 0.794 \\
\hline
\end{tabular}

Table 5 shows that the R Square value for competency is 0.758 . It is shown that atractiveness is able to describe the competency for $75.80 \% /$ Meanwhile, the rest of is explained by other variable. The $\mathrm{R}$ Square value for existence effect is 0,794 . It means that responsibility, competency, and emphaty can describe existance effect for $79.40 \%$, and the rest of it is described by other variable.

\section{Discussion}

\section{The Influence of Responsibility Towards Existence Effect}

Responsibility is not significant toward existence effect. This means that responsibility has no influence toward existence effect. The results of this research are not in accordance with the statement from University of Birmingham (2010) on "Lecturer in Urban Planning and Resilience". It is stated that one of the responsibilities of a lecturer is teaching and learning at all levels and study programs of University, i.e. undergraduate, postgraduate and / or higher research degree students. The lecturers also plan and review their own teaching approaches so that the lecturer can evaluate the learning activities. As the result, students are able to implement the material in the reality. However, these results are in line with research conducted by Sofyanti (2007) who examined the effect of teacher professionalism on student achievement. She found that there was no significant effect between teacher 
professionalism on student achievement. A teacher can be considered as professional by his responsibility in carrying out all his services. Professional teachers are teachers who are able to conduct his responsibility as a teacher to their students.

The lecturer plans well the lecture activities. However, the lecturers plan the activities only at the beginning to near the end of the lecture, sometimes until the middle of the semester. This is why, the responsibility variable does not influence the existence effect of students. During one semester (13 meetings) the lecturer always completes the meeting without missing anything, unfortunately at the end of the meeting the lecturer does not prepare the lecture material properly. Lecturers are always responsible for completing lecture material during 13 meetings. It's just possible at the last meetings the lecture material delivered is less than optimal. The first reason is because of the replacement of lecture hours. It often happens when in one semester, sometimes at certain meetings lecturers cannot teach the class. It may be caused by red date, there are needs both personal and organizational, and so forth. In order to replace the vacant meeting sometimes it is very difficult to find another meeting, since students and lecturers have different schedule. It will be more difficult if it approaches the midterm or the end of the semester, because many other lecturers will also have make up class.

\section{The Influence of Attractiveness Towards Competency}

Attractiveness has a significant influence toward competency. From the results of the study, it is found that the practical learning method indirectly increased the competency of the lecturer. Lecturers who teach using practical methods, means that the lecturer has presented the material in an interesting way, clear, understandable, involve the student interaction, also have used a variety of styles and methods of presenting lectures. One of the indicators of increased competency is shown by the lecturer correlates the material with the real examples in life, linking the material with Islamic values input, and the lecturer master the material / having sufficient knowledge with the field of study.

The results also showed that lecturers not only teach but also interact with the students. It is reflected through lecturers' evaluation. The students stated that: lecturers can interact with students well, the material is well-delivered by interacting, the class is interactive, the lecturers often interacting and explaining in detail, the material presentation is good, and many others. It can be concluded that lecturers use active interaction techniques. In addition, the lecturers also conduct visual interaction. For example, the lecturers deliver the material straight to the point or not too poetic, pay attention to speech intonation, paused in the middle of an explanation, have an eye contact in teaching, smiling and sometimes joking, using facial expressions and so forth.

Lecturers deliver the material in a clear and understandable way. Usually the students will easily understand the material if the lectures give real example which can be implemented in the real life. This shows that lecturers must have examples of real experiences about how does the material can be implemented in the real life. So that. only theory but students will know the reality in the field of their study. This fact also shows that the method applied by the lecturer has been able to improve the lecturers' competency. In order to make the students understand the material, lecturers usually also link the material with Islamic values. We all know that this institution is an Islamic institution. Therefore, it is necessary to give example from Islamic institution especially UNISSULA. Lecturers also always include Islamic values in every material. For example in the Human Resource Management subject, in compensation material, the lecturer will explain the material both in general and supplemented with Islam. It will be about 
how does the Islamic perspective about compensation that must be given to employees.

Lecturers use a variety of styles and methods in presenting the material. One of the presentation methods is by using technology. Technology is a tool that can help lecturers to create an active and fresh atmosphere in the classroom. One of the benefits using existing technology, such as laptops, internet, projectors, is to change textbook into audio visuals so that the material become more interesting. Encouraging videos are also sometimes shown by lecturers as a support in the material delivery. Meanwhile, for the style, lecturers avoid standing in one position, because if the lecturer only stands in one position it seems monotonous and boring for students. As the result, the lecturers use mobile teaching method. By mobile teaching the lecturer can discuss the material closer with the students and help them understand more. Mobile teaching gives many benefits for lecturers. One of the benefits is there will be emotional involvement. By going for a walk, moving positions, the lecturers will also know more the class situation in detail and see the students one by one. The use of technology media as one of the learning methods in class makes lecturers deal with technology and the internet everyday. Accessing the internet makes the experience, knowledge and competence of lecturers increases. It means that lecturers have deeper knowledge in their field of study. This is very influential in increasing competency of lecturers.

\section{The Influence of Emphaty Towards Existence Effect}

Emphaty has a significant effect toward existence effect. The results of this study support the research from Callake and Clack (1988) which suggested that student motivation has a very decisive role in student success to achieve optimal learning achievement. Therefore, lecturers need to raise the student motivation by creating a conducive atmosphere. This atmosphere can be created by establishing two-way communication, using appropriate learning methods and supporting material, thus the learning process becomes interesting, students become enthusiastic in order to improve the student learning achievement.

Statistical calculations show that in its implementation, lecturers have enthusiasm and love to teach. This can be seen from the lecturers' evaluation which stated that lecturers are very enthusiastic and energetic in teaching, especially in the material delivery. Besides that, lecturers also like to motivate students in their class, especially the first semester students. Motivation given to first semester students will be far more frequent. It is because positive motivations will make them to have positive mindset and will be followed by their actions. Motivation can be done at all times, three of the best times is at the first meeting, the middle of the meeting or midterm, and at the end of the semester before the final semester examination. By giving motivations to students, students will be inspired to improve their learning motivation and achievement.

Lecturers' empathy towards their students can be done by the way the lecturer values their students, appreciate what students do and respect the opinions of students when discussion by being good listeners. If the student's answer is wrong, the lecturer will motivate that it is normal to have wrong answer for the first time, and the lecturer will continue to appreciate the student's answer. So there is something more important, namely the process and effort of students from not knowing to knowing.

Lecturers $\mathrm{s}$ able to make a fun learning situation. For lecturers many ways can be done in order to create a fun learning situation for students. For examples, first, attractiveness or attractive learning methods. Second, storytelling. It is a method of delivering material by telling inspirational stories for students so students can be interested and inspired. In addition, 
sometimes lecturers give assignments for students to analyze things and then ask them to present the analysis results in front of the class. Such a method can increase knowledge and experience for both students and lecturers. Then it could also be a question and answer method, a questioning technique to attract the attention of the listener and make the listener ready for what will be conveyed to the lecturer.

Lecturers care about the student understanding about lecture material. At the end of meeting after the delivery and discussion in class, the lecturer will make sure by asking students in advance whether there is material that has not been understood and which parts have not been understood. In addition, the lecturer also encourages students to ask by giving opportunity and motivation for students to dare to ask questions. The lecturer reveal that asking questions can erase ignorance and improve understanding and thinking.

\section{The Influence of Competency Towards Existence Effect}

Competency has positive but not significant influence toward existance effect. This means that competency does not have a significant effect toward existance effect. Although competency has been influenced by attractiveness, competency still has no influence on increasing existence effect of students. The results of this research reject the research results Schaltz (1970) stated that knowledge significantly influences individual work morale. The research revealed that initial knowledge has a strong contribution toward the student knowledge about subject and objectives during the learning process. This result indicates that the lecturer does not associate the lecture material with Islamic values. In other words, it has been implemented but it is still lacking. Therefore, the variable of competency has a positive but not significant influence.

In every delivery of lecture material, the lecturer always explains and provides a real example of how it is implemented in the real life. This is commonly referred to analogy and case study. Analogy and case study help students to have better understanding. Meanwhile, in examination questions, the lecturer always asks students to give examples and links the material with Islamic values. Unfortunately, this indicator is not carried out by lecturers.

Lecturers master the material or have an adequate broad knowledge in the field of their study. The course that is taught by a lecturer is a division of majors or study programs, so there are some subjects that lecturers do not really master such as economics development. For each meeting the lecturer will always learn in advance about the material that will be given to students. Sometimes there are themes that the lecturer has not known at all and the situation requires the lecturer to learn from the beginning first. So for subjects with such cases lecturers will have more discussions in class with students. If the lecturer does not know about some questions or about new things the lecturer will openly tell the students and will urge each other to find out the answer and then it will be discussed at the next meeting.

\section{CONCLUSION}

Referring to the problem formulation of this research about how to increase the existence effect of human resources in teaching and learning activities in the classroom, where the human resources in this research are students. Based on the research results, it can be concluded that in order to increase the existence effect of human resources in the organization. it can be improved through increasing the empathy of lecturers with students. Thus the higher the empathy of a lecturer in class activities, the existence effect of students will increase as well. Meanwhile, in order to improve the competency of a lecturer. it can be improved through increasing the attractiveness or learning methods. So that the higher the level of attractiveness of a lecturer in class 
activities, the lecturers' competency will also increase. Responsibility cannot explain the existence effect of students. This is due to the fact that lecturers may not implement indicators of responsibility itself. The responsibility indicator is lecturer plans well the lecture activities and the lecturer is responsible for the completion of the lecture material. So if responsibility can be increased, then responsibility will also be able to increase the existence effect of students.

The limitations of this research are: the test results used Partial Least Square (PLS) method, which shows that the R-square value for competency is 0.758 or able to predict the model reaches $75.80 \%$ while the remaining $24.2 \%$ is caused by variables outside the model. This shows that there are other variables outside this research which have influence, so the future research still need other variables that are more relevant. The other limitation is, the variables that influence the increased of existence effect or independent variables which consist of attractiveness, competency, responsibility, and empathy are all organizational factors. So there are other factors or dimensions that have influence, apart from organizational factors.

Meanwhile the future research agenda that can be carried is related to other variables that can influence the increase of competency of a lecturer. The further research also need to include factors that can increase the competency of lecturers, so that a lecturer in a university is not only fulfill the quantity but also fulfill the quality. Since the variables that influence the increase of existence effect or independent variables, are all organizational factors, further research needs to add other factors besides organizational factors, including individual factors and environmental factors (family and colleagues).

\section{REFERENCES}

Agung, Iskandar. (2010). Meningkatkan Kreativitas Pembelajaran Bagi Guru. Jakarta: Bestari Buana Murni.
Baharuddin, Eka Nur Wahyuni. (2007). Teori Belajar dan Pembelajaran.Bandung: PT. Remaja Rusda Karya.

BahriS. (2002). Strategi Belajar Mengajar. Cetakan Kedua, Jakarta, Rineka Cipta.

Callahan, Joseph F. And Clark, Leonard H. (1988). Planning for Competence. New York: Macmillan Publishing Co.

Dharma, Surya. (2005). Manajemen Kinerja Falsafat Teori dan Penerapannya. Pustaka Pelajar, Yogyakarta.

Dimyati dan Mudjiono. (2009). Belajar dan Pembelajaran. Jakarta: Rineka Cipta.

Dirjen Dikti. (2010). Buku Pedoman Sertifikasi Pendidik Untuk Dosen Tahun 2010. Buku II Penyusunan Portopolio. Direktorat Jenderal Pendidikan Tinggi. Jakarta.

Febri, Nilasari. (2011). Pengaruh Kepribadian dan Profesionalitas Guru Ekonomi-Akuntansi terhadap Prestasi Belajar Siswa Program Ilmu Pengetahuan Sosial untuk Mata Pelajaran Ekonomi-Akuntansi SMA Negeri se-Kabupaten Kebumen. Skripsi. Semarang: Fakultas Ekonomi Unnes.

Ferdinand, Augusty. (2005). Structural Equation Modelling dalam Penelitian Manajemen. Semarang: BP UNDIP.

Ghozali, Imam. (2011). "Aplikasi Analisis Multivariate Dengan Program SPSS". Semarang: Badan Penerbit Universitas Diponegoro.

Gibson, dkk. (1997). Organisasi. Binarupa Aksara, Jakarta.

Hamalik O. (1997). Proses Belajar Mengajar. Jakarta, PT. Bumi Aksara.

Hanik, Mudayati. (2008). Hubungan persepsi mahasiswa tentang metode pembelajaran dan penguasaan materi dosen dengan prestasi belajar mahasiswa prodi D3 Kebidanan Universitas Tulungagung. Surakarta: Universitas Sebelas Maret. 
Hidayati dkk. (2008). Pengembangan Pendidikan IPS SD. Jakarta: Direktorat Jenderal Pendidikan Tinggi Departemen Pendidikan Nasional.

Hidayati, R. (2009). Asuhan Keperawatan pada Kehamilan Fisiologis dan Patologis. Jakarta: Salemba Medika.

Kementerian Agama RI. (2011). Petunjuk Teknis Workshop Peningkatan Kompetensi Dosen Perguruan Tinggi Agama Islam. Jakarta: Direktorat Jenderal Pendidikan Islam Direktorat Pendidikan Tinggi Islam.

Mulyasa, E. (2002). Manajemen Berbasis Sekolah, Konsep, Strategi dan Suplementasi. Bandung: PT. Remaja Rosdakarya.

Nasution, S. (2000). Berbagai Pendekatan dalam Proses Belajar dan Mengajar. Jakarta: Bumi Aksara.

Nurdin, Ali, dkk, (2006). Manajemen Sumber Daya Manusia. Faza Media, Jakarta.

Purwanto, Budi. (2004). Hubungan Antara Kenyamanan, Kesejahteraan dan Kreativitas Guru Dalam Proses Belajar Mengajar di SLTP SeKecamatan Pati. Semarang: PPS UNNES.

Putra, Antonius Dhimas H. (2011). Hubungan Tingkat Attractiveness Elemen-Elemen Tayangan Iklan Televisi Dengan Minat Pembelian Produk. Yogyakarta: Univesitas Atma Jaya.

Putra, Mukhlis Filiyang. (2013). Daya Kreativitas Guru Dalam Mengajar Sejarah Terhadap Motivasi Dan Prestasi Belajar Siswa Pada Kelas XII IPS SMASe- Kecamatan Jepara Tahun Ajaran 2012/2013. Semarang: Universitas Negeri Semarang.

Reo, Susanto. (2008). Pengaruh Attractiveness, Trustworthiness, Expertise Dan Power Model Iklan Terhadap Niat Beli Ulang Konsumen. Yogyakarta. Universitas Sonata Dharma.
Sofyanti, Reny. (2007). Pengaruh Profesionalisme Guru Terhadap Prestasi Belajar Siswa Kelas IX Di SMP Negeri 11 Pasuruan. Malang: UIN Maulana Malik Ibrahim.

Spencer. M. Lyle. Jr. \& Signe. M Spencer. (1993). Competency At Work. Models For Superior Performance. Jhon Wiley\&Sons Inc. New York.

Sri Mutmainah. (2008). Jurnal Plans Penelitian Ilmu Manajemen \& Bisnis Pengaruh Motivasi dan disiplin kerja terhadap kinerja kerja karyawan pada PT Panen Lestari Internusa Medan Vol.III No :1 Maret. Universitas Negeri Medan.

Sukari. (2013). Pengaruh Kompetensi Guru, Lingkungan Keluarga, Lingkungan Masyarakat, Lingkungan Sekolah Dan Motivasi Belajar Terhadap Prestasi Belajar Siswa Pada Mata Pelajaran Ekonomi Kelas Xi Ips Di Sma Negeri 1 Batang Tahun Ajaran 2012/2013. Semarang: Universitas Negeri Semarang.

Supriyanto S. (2002). Metodologi Riset. Fakultas Kesehatan Masyarakat Universitas Airlangga. Surabaya.

T. Hani H. (2000). Manajemen. Edisi 2. Cetakan Keenam Belas. Yogyakarta: BPFE Yogyakarta.

Undang-undang no.20 Tahun 2005 tentang Sistem Pendidikan Nasional.

Uno Hamzah. B. (2010). Perencanaan Pembelajaran. Jakarta: Bumi Aksara.

Warsito, Ardi,dkk. (2012). Pendidikan Lingkungan Keluarga, Sekolah, dan Masyarakat.

http://www.infodiknas.com/259-

Pendidikan-lingkungan-keluargasekolah-dan -masyarakat.html.

Yahya, Nordin. (2010). The Effects of Extrinsic Motivational Factors in Learning among Students in Secondary School in Negeri Sembilan. International Journal of Psychological Studies 
